\title{
BTBD18 Gene
}

National Cancer Institute

\section{Source}

National Cancer Institute. BTBD18 Gene. NCI Thesaurus. Code C126629.

This gene may be involved in protein ubiquitination. 